\title{
Effects of Psychological Factors on Entrepreneurial Activities among Agricultural Students of Kashmir
}

\author{
Shazia Tariq*, Rizwana Malik, Gohar Bilal Wani, Tasaduq H. Shah, \\ Bilal Ahmad Bhat, Ishrat Aishi and T.A. Rather
}
Faculty of Fisheries, Sher-e-Kashmir University of Agricultural Sciences \& Technology of Kashmir (SKUAST-K), Rangil, Ganderbal, J\&K, India

*Corresponding author

\begin{tabular}{|l|}
\hline Ke y w or d s \\
$\begin{array}{l}\text { Entrepreneurship, } \\
\text { psychological } \\
\text { factors, Agricultural } \\
\text { students, Kashmir. }\end{array}$ \\
\hline Article Info \\
\hline $\begin{array}{l}\text { Accepted: } \\
\text { 15 December } 2019 \\
\text { Available Online: } \\
\text { 20 January } 2020\end{array}$ \\
\hline
\end{tabular}

\author{
A B S T R A C T
}

\section{Introduction}

Entrepreneurship activities can be found in almost every sphere of world, as it has been recognized as the determinant or pivotal element of economic growth and development (Dilip, 2017). The entrepreneurship leads to the creation of small and medium scale businesses, providing employment opportunities, income generation, uplifting of standard of living, and utilization of human, material and financial resources of a country in the right direction (Idris, 2017). Thus, many countries have placed intensive and frantic efforts and programmes towards development of entrepreneurship (Pulka et al., 2014). It has been found that countries development and job growth is known to be 
greatly dependent on entrepreneurship (Kumar et al., 2017). However, the rate of growth for entrepreneurship varies from time to time and from country to country. But, the fact is that it has still positive and clear impact on the growth of economy (Reynolds, 1995). Due to the very fast growth of entrepreneurship development in the world, many studies (Kumar et al., 2017; Tiwari et al., 2017; Zulfiqar et al., 2017) have been thus conducted in order to view the factors that play an important role in determining the intention of becoming an entrepreneur.

However, it has been found that most of the studies focused on typically identifying preexisting entrepreneur's and already wellestablished venture while avoiding large pool of potential entrepreneurs, i.e., students. Thus, the finding with regard to graduates and ongoing students seems to be still questionable to generalize (Reitan, 1997). Entrepreneurship development in India has enormous potential in terms of diversification of rural employment and occupations (Yadav et al., 2017). Agriculture is an indispensable component of rural economy act as catalyst for improving the socioeconomic conditions of the rural people (Sadashive et al., 2017). Thus, entrepreneurial development is a crucial way to make rural people more competent in agriculture, generate employment as well as improve productivity and economy (Monavari et al., 2013). Dynamic entrepreneurs like Agricultural students are considered to be the agent of change in a society (Tong et al., 2011).

The entrepreneurial intensions of Agricultural students play a very important role in generating new employment and setting up new business. Thus, considering the importance of the entrepreneurship and prospects in agriculture sector in India, there is a need to harness the potential of Agricultural students. Hence, the present study was contemplated to analyze the behavior of agricultural students towards entrepreneurship with the objective to assess the impact of psychological characteristics of agricultural students on their entrepreneur behavior.

\section{Materials and Methods}

\section{Sampling procedure}

The present study was conducted in the Shere-Kashmir University of Agricultural Sciences and Technology of Kashmir (SKUST-K), Srinagar, Kashmir. Sample selection procedure for the study was consisted of purposive sampling of faculties followed by simple random sampling (Ray and Mondol, 2004) of postgraduate Agricultural students. Out of seven faculties of the SKUST-K, four faculties namely, Faculty of Agriculture, Wadura, Sopore, Faculty of Horticulture, Shalimar, Srinagar, Faculty of Fisheries, Rangil, Ganderbal and Faculty of Veterinary \& Animal Husbandry, Suhama, Ganderbal were purposively selected. Thirty (30) postgraduate Agricultural students were randomly selected from each selected Faculty. The final sample size comprised of one hundred and twenty (120) postgraduate students belonging to various selected faculties for the field study.

\section{Data collection}

A descriptive survey design was used to collect data from the participants on the variables of present study. It is a research design which states clearly the characteristics of a particular situation or group or individual (Rudhumbu et al., 2016). The data were collected through personal interviews of the respondents using a well-structured pre-tested interview schedule (Kumar, 2012). A selfadministered interview schedule was used for collection of data to avoid the respondents 
from being influenced by researchers. The interview schedule employed a 5-point Likert scale. The interview schedule was constructed on the basis of reconnaissance survey of the faculties, discussion with the postgraduate Agricultural students, consultation with the experts and earlier related works.

The interview schedule possessed entrepreneurial information on leadership ability of respondents, career aspiration of the respondents, attitude towards entrepreneurship, technical confidence, perception regarding fear to engage in entrepreneurship and perception regarding family and relatives support. Interview in most cases were conducted in a group of postgraduate Agricultural students in order to get in-depth information. In group setting, the respondents were given 10-20 minutes to answer the questions. It was also ensured that respondents were given enough time to answer the questions and to obtain a high response rate.

\section{Data analysis}

The descriptive statistics viz., frequency (f), percentage $(\%)$, average (x), standard deviation and range (Snedecor and Cochran, 1967) were applied for the data analysis. The data were analyzed using Statistical Package for Social Sciences (SPSS) software version 16. The results were displayed through tables for meaningful interpretation of the data in simpler way.

\section{Results and Discussion}

\section{Leadership ability}

The data presented in Tablel regarding overall level of leadership ability of the respondents revealed that the majority $(68.33 \%)$ of the respondents had medium level of leadership ability, followed by respondents having low level of leadership ability (19.16\%), while (12.50\%) were had high level of leadership ability.

\section{Career aspiration}

The respondents were asked questions in the interview schedule related to their occupation and for future career plan. The data revealed that respondents wanted to become government officers in agricultural department with highest mean value of (3.32), followed for higher studies (3.25), while the students who wanted to be a professor in their respective fields (3.10), employment in nonagricultural dept. (2.91), employment in large/small/medium enterprise (2.62) and the least preference was given to establish their own business but not agricultural with an overall mean score of (2.34) (Table 2).

\section{Attitude towards entrepreneurship}

The results of the data presented in Table 3 regarding overall level of attitude towards agricultural entrepreneurship of the respondents revealed that majority $(71.66 \%)$ of the respondents had favorable attitude towards entrepreneurship, followed by the respondents $(17.50 \%)$ had less favorable attitude towards agricultural entrepreneurship, while only $(10.83 \%)$ of the respondents had favorable attitude towards agricultural entrepreneurship.

\section{Technical confidence}

To measure the technical confidence of the students related to Agriculture and allied sectors, the responses obtained were analyzed using overall mean. The analyzed data referred that the respondents had highest confidence in setting up fish feed enterprise/agro tourism/fertilization businesses/animal health management business with overall mean (3.11), while as 
least preference was given to provision of extension consultancy services with overall mean of (2.72) (Table 4).

\section{Perception regarding fear to engage in entrepreneurship}

Data presented in Table 5 on perception regarding fear to engage in entrepreneurship revealed that the maximum respondents perceived fear of high financial risks followed by political conflicts, market risks, lack of awareness, access to finance, any other and least to gender with the percentage values of (83.33\%), (78.33\%), (76.66\%), (73.50), $(47.50 \%), \quad(26.66 \%) \quad$ and $\quad(23.33 \%)$ respectively.

\section{Perception regarding family and relatives support}

The results depicted in Table 6 on perception regarding family support revealed that the majority (90.00\%) of the respondents had perception that their family and relatives will support them morally, if they establish a new business. However, least of the respondents $(73.33 \%)$ perceived that their family and relatives will financially support them in establishing a new business.

The findings of the present study revealed that most of the respondents $(68.33 \%)$ had medium level of leadership ability. The findings are in corroboration with Kumar et al., (2017). This could be due to the reason that many of the respondents addressed that they understand their culture and identity and are able to achieve their goals if have direct supervision, thus, articulating their personal leadership abilities. The most notable results of the study with regard to career aspiration revealed that among the six choices opted by the students, establishing own business other than agriculture ranked sixth and to become Government officer in agricultural department was ranked I, thus it clearly indicated that majority of the students still want to go for low risk activities which have secured income. This could be due to lack of motivation and fear regarding political conflicts in our valley. Similar findings has been reported by Green and Pryde (1990) in which they revealed that maximum of University students wanted to be employed rather than to be self-employed which could be possibly explained by lack of motivation. Further, the results depicted that the respondents of Agricultural University had medium attitude towards entrepreneurship. The same statement is supported by Chaurasiya et al., (2017). This could be due to the reason that as most of them agreed that lack of employment in public sector has doubled necessity of entrepreneurship compared with other graduates and agricultural students should think about entrepreneurship which is effective in reducing unemployment.

As per the findings it can be inferred that many of the students from different faculties had shown a good confidence in setting up fish feed enterprise/agro tourism/fertilizer businesses/animal health management business with overall mean (3.11), thus accounting them as most preferred areas with highest rank of I. However, they had shown less confidence in many important areas as fish health and management clinic, food processing units, dairy enterprise, greenhouse grower, aquaculture and hatchery production of fry and fingerling etc. Internship in the university had many shortcomings and failed to motivate majority of the students to be entrepreneurs. All these enterprises required great expertise and skill. However, the students felt they lacked the required skills to start such enterprise. Though, they were trained in the University in all such subject matter areas, but that was far less than the required expertise. The results also signified 
that majority of respondents with respect to perception regarding fear to engage in entrepreneurship revealed that fear of financial risk was one of the major reasons for creating negative mindset among respondents in terms of confidence, initiatives and creativity, ultimately resulting in a negative perception towards entrepreneurship as career choice. The findings are in consistent with the results of Green and Pryde (1990). For establishing any business the family support plays one of the important roles for success. The results indicated that the majority $(90.00 \%)$ of the students agreed that their family and relatives will support them morally while only $(73.33 \%)$ had agreed that their family and relatives will support them financially. The findings are in line with Kumar (2017). The positive attitude of parents towards taking up of entrepreneurial activities by their children could play an important role in encouraging students for becoming an entrepreneur. Hence, only prerequisite is to provide them direction by organizing trainings regarding all the aspects required for being successful entrepreneurs. Similar findings has been put forth by Ijaz et al., (2012) in which they stated that family and friends has strong influence on entrepreneurial behavior of a person, as their moral and financial support helps them to take risks and inculcate new ideas in their business.

The study led to conclude that the University should organize programmes wherein leadership skills could be inculcated among the students. The attitude of respondents towards entrepreneurship was moderately to less favourable. Thus moderately favourable attitude can be easily converted into favourable attitude by organizing interactive sessions with successful entrepreneurs, site visit to near enterprise, single window system for getting license/clearances from different departments and facility of loans with easy repayment conditions.

Table.1 Leadership ability of respondents $(\mathrm{N}=120)$

\begin{tabular}{|c|c|c|c|c|c|c|c|c|c|c|}
\hline \multirow{2}{*}{$\begin{array}{l}\text { Level of leadership } \\
\text { ability }\end{array}$} & \multicolumn{2}{|c|}{ Fisheries } & \multicolumn{2}{|c|}{ Agriculture } & \multicolumn{2}{|c|}{ Horticulture } & \multicolumn{2}{|c|}{ Vet. \& AH } & \multicolumn{2}{|c|}{ Total } \\
\hline & No. & $\%$ & No & $\%$ & No. & $\%$ & No. & $\%$ & No. & $\%$ \\
\hline $\begin{array}{l}\text { Low } \\
(\text { up to 46) }\end{array}$ & 3 & 10.00 & 5 & 16.67 & 9 & 30.00 & 7 & 23.33 & 23 & 19.16 \\
\hline Medium (47 to 59) & 25 & 83.34 & 24 & 80.00 & 15 & 50.00 & 18 & 60.00 & 82 & 68.33 \\
\hline High ( above 60) & 2 & 6.66 & 1 & 3.33 & 6 & 20.00 & 5 & 16.67 & 15 & 12.51 \\
\hline Total & 30 & 100 & 30 & 100 & 30 & 100 & 30 & 100 & 120 & 100 \\
\hline
\end{tabular}

Table.2 Major career preferences of respondents $(\mathrm{N}=120)$

\begin{tabular}{|c|c|c|c|}
\hline Statement & Overall mean & $\begin{array}{c}\text { Overall } \\
\text { SD }\end{array}$ & Rank \\
\hline To go for higher studies & 3.25 & 0.889 & II \\
\hline To be Professor & 3.10 & 0.972 & III \\
\hline To become Govt. officer (agricultural deptt.) & 3.32 & 0.765 & I \\
\hline To become Govt. officer (non-agricultural deptt.) & 2.91 & 0.962 & IV \\
\hline Employment in L/S/M enterprise & 2.62 & 0.949 & V \\
\hline Establish own business but not Agricultural & 2.34 & 1.060 & VI \\
\hline
\end{tabular}


Table 3 Attitude towards entrepreneurship (N=120)

\begin{tabular}{|c|c|c|c|c|c|c|c|c|c|c|}
\hline \multirow{2}{*}{$\begin{array}{l}\text { Level of attitude towards } \\
\text { entrepreneurship }\end{array}$} & \multicolumn{2}{|c|}{ Fisheries } & \multicolumn{2}{|c|}{ Agriculture } & \multicolumn{2}{|c|}{ Horticulture } & \multicolumn{2}{|c|}{ Vet. \& AH } & \multicolumn{2}{|c|}{ Total } \\
\hline & No. & $\%$ & No & $\%$ & No. & $\%$ & No. & $\%$ & No. & $\%$ \\
\hline Less favourable (up to 23) & 6 & 20.0 & 6 & 20.00 & 2 & 6.67 & 7 & 23.33 & 21 & 17.51 \\
\hline $\begin{array}{l}\text { Moderately favourable (24 to } \\
\text { 31) }\end{array}$ & 20 & 66.67 & 21 & 70.00 & 27 & 90.0 & 18 & 60.00 & 86 & 71.66 \\
\hline Favourable (above 32) & 4 & 13.33 & 3 & 10.00 & 1 & 3.33 & 5 & 16.67 & 13 & 10.83 \\
\hline Total & 30 & 100 & 30 & 100 & 30 & 100 & 30 & 100 & 120 & 100 \\
\hline
\end{tabular}

Table 4 Distribution of respondents according to their technical confidence $(\mathrm{N}=120)$

\begin{tabular}{|l|l|l|l|}
\hline Statement & $\begin{array}{l}\text { Overall } \\
\text { mean }\end{array}$ & Overall SD & Rank \\
\hline $\begin{array}{l}\text { Hatcheries and Production of fish, fingerling for Aquaculture/Agricultural equipment } \\
\text { rental/To become g greenhouse grower/Poultry enterprise live stock feed production }\end{array}$ & 2.85 & 0.909 & VI \\
\hline $\begin{array}{l}\text { Fish processing unit/Spice production/food processing unit/Dairy enterprise } \\
\text { Fishing gear and craft manufacturing enterprise/Bulk foodstuff wholesaling/Value } \\
\text { addition centres/ goat or sheep farming }\end{array}$ & 2.99 & 0.851 & II \\
\hline $\begin{array}{l}\text { Provision of extension consultancy service } \\
\text { Fish health \& management clinic/Food processing units/Grocery e-shopping } \\
\text { portal/Frozen chicken production }\end{array}$ & 2.95 & 0.934 & V \\
\hline $\begin{array}{l}\text { Setting ornamental business/Post harvesting centres/Small or Hi tech nurseries/Setting } \\
\text { of IT Kiosks }\end{array}$ & 2.98 & 0.948 & VII \\
\hline $\begin{array}{l}\text { Fish feed manufacturing enterprise/ Agro tourism/Fertilization business/Animal health } \\
\text { management business }\end{array}$ & 3.11 & 1.008 & III $^{\mathrm{a}}$ \\
\hline
\end{tabular}

Table.5 Distribution of respondents according to their perception regarding fear to engage in entrepreneurship ( $\mathrm{N}=120)$

\begin{tabular}{|c|c|c|c|c|c|c|c|c|c|c|}
\hline \multirow[t]{3}{*}{ Attribute } & \multicolumn{8}{|c|}{ Faculty } & \multirow{2}{*}{\multicolumn{2}{|c|}{ Overall }} \\
\hline & \multicolumn{2}{|c|}{ Fisheries } & \multicolumn{2}{|c|}{ Agriculture } & \multicolumn{2}{|c|}{ Horticulture } & \multicolumn{2}{|c|}{ Vet. \& AH } & & \\
\hline & No. & $\%$ & No. & $\%$ & No. & $\%$ & No. & $\%$ & No. & $\%$ \\
\hline Financial risk & 25 & 83.33 & 27 & 90.00 & 23 & 76.66 & 25 & 83.33 & 100 & 83.33 \\
\hline Access to finance & 24 & 80.00 & 24 & 80.00 & 20 & 66.66 & 20 & 66.66 & 88 & 73.33 \\
\hline Gender & 8 & 26.66 & 6 & 20.00 & 6 & 20.00 & 8 & 26.66 & 28 & 23.33 \\
\hline Political conflicts & 18 & 60.00 & 23 & 76.66 & 21 & 70.00 & 23 & 76.66 & 85 & 78.33 \\
\hline Market risk & 24 & 80.00 & 22 & 73.33 & 23 & 76.66 & 23 & 76.66 & 92 & 76.66 \\
\hline Lack of awareness & 9 & 30.00 & 21 & 70.00 & 18 & 60.00 & 9 & 30.00 & 57 & 47.50 \\
\hline Any other & 10 & 33.33 & 6 & 20.00 & 8 & 26.66 & 8 & 26.66 & 32 & 26.66 \\
\hline
\end{tabular}

Table.6 Distribution of respondents according to their perception regarding family and relatives support $(\mathrm{N}=120)$

\begin{tabular}{|c|c|c|c|c|c|c|c|c|c|c|}
\hline \multirow[t]{3}{*}{ Attribute } & \multicolumn{8}{|c|}{ Faculties } & \multirow{2}{*}{\multicolumn{2}{|c|}{ Overall }} \\
\hline & \multicolumn{2}{|c|}{ Fisheries } & \multicolumn{2}{|c|}{ Agriculture } & \multicolumn{2}{|c|}{ Horticulture } & \multicolumn{2}{|c|}{ Vet. \& AH } & & \\
\hline & Yes & $\%$ & Yes & $\%$ & Yes & $\%$ & Yes & $\%$ & Yes & $\%$ \\
\hline $\begin{array}{l}\text { Financial } \\
\text { support }\end{array}$ & 20 & $\begin{array}{l}66.6 \\
6\end{array}$ & 26 & 86.66 & 20 & $\begin{array}{l}66.6 \\
6\end{array}$ & 22 & 73.33 & 88 & $\begin{array}{l}73.3 \\
3\end{array}$ \\
\hline Moral support & 29 & $\begin{array}{l}96.6 \\
6\end{array}$ & 29 & 96.66 & 23 & $\begin{array}{l}76.6 \\
6\end{array}$ & 27 & 90.00 & 108 & $\begin{array}{l}90.0 \\
0\end{array}$ \\
\hline
\end{tabular}


The study also revealed that majority of respondents aspired for government jobs rather than starting their own business. This was due to low motivational factor and risk taking propensity among students. Therefore, University should plan their affairs in such a way so that it could extol thinking and planning abilities of the students and hence reducing their risk of start new business.

Also University should provide incumbent environment wherein, entrepreneurial success, innovation and risk taking capacity of many renowned entrepreneurs is celebrated so as to have, in abundance, inspirational role models to inspire aspiring students to start and grow new ventures. Skill enhancement among students should be done as per their field of interest and by sensitizing students with more of practical work from the first year so that they could be aware regarding their abilities and interest by the end of their degree programme and thus could be easy for them to start up their business venture. It is also recommend that government should allocate special funds to banks in order that students who intend to invest in various areas could be loaned and these resources should be solely allocated for them. The study also revealed that family and relatives play a significant role in governing attitude of students towards entrepreneurship. Thus, the elders of the families, at their individual level should encourage their children for setting up business ventures by developing entrepreneurial knowledge and skills among them through sharing, learning and exchanging of information about entrepreneurship programmes, events, resources or by providing financial assistance to start their career as entrepreneur.

\section{Acknowledgement}

Authors acknowledge their heartfelt indebtedness to the respondents for their honest data and knowledge sharing, which formed the basis of this research work. The scientists of the Faculty of Fisheries, SKUAST-K, Rangil, Ganderbal, Kashmir deserve special applaud for providing moral support during my field-work.

\section{References}

Chaurasiya, K. K., Maratha, P. and Badodiya, S. K. 2017. Factors affecting entrepreneurial behaviour of dairy farmers. Hind Agricultural Research and Training Institute, 12(1): 23-30.

Dilip, K. 2017. A Study on Entrepreneurial Behaviour Among the Students at Indira Gandhi Krishi Vishwavidalaya, Raipur in Chhattisghar. Ph.D. Thesis. Department of Agricultural Extention Collage of Agriculture.

Green, S. and Pryde, P. 1990. Black entrepreneurship in America. New Brunswick. NJ, Transactions publishing.

Idris, A. A. 2017. Entrepreneurial Intention among Postgraduate Students in Nigerian Universities: Conceptual Review. American Finance and Banking Review, 1(1): 12-23.

Ijaz, M., Yasin, G. and Zafar, M. J. 2012. Cultural factors Effecting Entrepreneurial Behaviour among Entrepreneurs. Case Study of Multan, Pakistan.

Kumar, D. 2017. A Study on Entrepreneurial Behaviour Among the students At Indira Gandhi Krishi VIshwavidyalaya, Raipur in Chhattisgarh. Ph.D. (Agrill. Extension) Thesis, Indira Gandhi Krishi Vishwavidyalaya, Raipur (C.G).

Kumar, D., Sengar, R. S., Shrivastava, P. and Singh, P. R. 2017. Influencing factors of student's attitude towards entrepreneurship. Journal of Pharmacognasy and Phytochemestry, 1: 743-747. 
Kumar, R. 2012. Research Methodology - A step by step guide for beginners. Dorling Kindersley (India) Pvt. Ltd., New Delhi, India.

Monavari, F. F., Dehghan, S. A., Lotfian, A. and Salehi, L. 2013. Analysis of factors affecting the development of an entrepreneurial student. International journal of Advanced Biological and Biomedical Research, 1(3): 246-259.

Pulka, B. M., Rikwentishe, R. and Ibrahim, B. 2014. An Evaluation of Students' Attitude towards Entrepreneurship Education in some Selected Universities in North East Nigeria. Global Journal of Management and Business Research: A Administration and Management, 14: 8-13.

Ray, G. L. and Mondol, S. 2004. Research Methods in Social Sciences and Extension Education, Kalyani Publishers, New Delhi, pp. 66-76.

Reitan, B. 1997. Entrepreneurs intention: A combined models approach. Proceedings of the $9^{\text {th }}$ Nordic Small Business Research Conference, Lillehammer, Norway.

Reynolds, P. D. 1995. Who starts new firms? Linear additive versus interaction based models. Proceedings of the BabsonKauffman entrepreneurship research conference, London business school: United Kingdom.

Rudhumbu, N., Svotwa, S., Munyanyiwa, T. and Mutsau, M. 2016. Attitudes of Students towards Entrepreneurship Education at two selected Higher Education Institutions in Bottswana: A
Critical Analysis and Reflection. Academic Journal of Interdisciplinary Studies, 5(2): 83-92.

Sadashive, S. M., Pathade, S. S., Sawant, M. N., Ramesh, N. and Pordhiya, K. I. 2017. Entrepreneurial Behaviour of Dairy Farmers: A Study in Marathwada Region of Maharashtra. International Journal of Current Microbiology and Applied Sciences, 6(7): 97-101.

Snedecor, G. W. and Cochran, W. G. 1967. Statistical Methods. Iowa State University Press, Ames, Iowa-50010.

Tiwari, P., Bhat, A. K. and Tikoria, J. 2017. An empirical analysis of the factors affecting social entrepreneurial intentions. Journal of Global Entrepreneurship Research 7(1): 9-14.

Tong, X. F., Tong, D. Y. K. and Loy, L. C. 2011. Factors influencing entrepreneurial intention among university students. International Journal of Social Sciences and Humanity Studies, 3(1): 1309-8063.

Yadav, A. and Kashyap, S. K. 2017. SocioEconomic, Personal and Psychological Characteristics Affecting Entrepreneurial Intention of Agricultural Students. International Journal of Current Microbiology and Applied Sciences, 6(7): 2241-2246.

Zulfiqar, S., Asmi, S., Asmi K. E., Sarwar, B. and Aziz, S. 2017. Measuring entrepreneurial readiness among youth in Pakistan through Theory of Planned Behavior (TPB) Based Approach. Business and Economic Research, 7(1): 149-167.

\section{How to cite this article:}

Shazia Tariq ${ }^{*}$, Rizwana Malik, Gohar Bilal Wani, Tasaduq H. Shah, Bilal Ahmad Bhat, Ishrat Aishi and T.A. Rather. 2020. Effects of Psychological Factors on Entrepreneurial Activities among Agricultural Students of Kashmir. Int.J.Curr.Microbiol.App.Sci. 9(01): 1668-1675. doi: https://doi.org/10.20546/ijcmas.2020.901.184 